\title{
Mowing Frequency and Plant Growth Regulator Effects on Dollar Spot Severity and on Duration of Dollar Spot Control by Fungicides
}

\author{
Alexander I. Putman, Former Graduate Research Assistant, Department of Plant Science and Landscape Architecture, University of \\ Connecticut, Storrs 06269; and John E. Kaminski, Assistant Professor, Department of Crop and Soil Sciences, The Pennsylvania State \\ University, University Park 16802
}

\begin{abstract}
Putman, A. I., and Kaminski, J. E. 2011. Mowing frequency and plant growth regulator effects on dollar spot severity and on duration of dollar spot control by fungicides. Plant Dis. 95:1433-1442.

Management of dollar spot (incited by Sclerotinia homoeocarpa) on golf course fairways is increasingly challenging. The objectives of this study were to determine the influence of mowing frequency and plant growth regulators (PGRs) on dollar spot severity and on the residual efficacy of fungicides for control of dollar spot. Two 4-month-long studies were conducted on 'Putter' creeping bentgrass (Agrostis stolonifera) maintained as a fairway at the University of Connecticut. Treatments were arranged in a three-by-three-by-five factorial that assessed the influence of mowing frequency $\left(2,4\right.$, or 6 days week $\left.{ }^{-1}\right)$ and PGRs (paclobutrazol, trinexapac-ethyl, or none) on dollar spot control by five fungicide treatments (boscalid, chlorothalonil, iprodione, propiconazole, or none). Turf was mowed in the afternoon hours to minimize the confounding effect of mowing frequency on leaf wetness duration. Treatments were initiated in the late spring of 2007 and 2008, and each fungicide treatment was reapplied only when dollar spot exceeded a threshold of five infection centers plot $^{-1}$. In the absence of fungicides, dollar spot severity was reduced by 63 to $90 \%$ in plots treated with

paclobutrazol and by 13 to $55 \%$ in plots treated with trinexapac-ethyl.

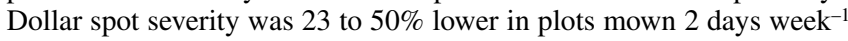
compared with those mown 6 days week ${ }^{-1}$. In cases where a significant interaction was observed between mowing frequency and PGRs, dollar spot was reduced on most rating dates in plots treated with trinexapacethyl that were mown 2 days week ${ }^{-1}$ compared with those mown 6 days week $^{-1}$. Survival analysis of days until threshold was met revealed that duration of control of fungicides in plots receiving paclobutrazol were 28 to $84 \%$ longer compared with plots not receiving PGR. Duration of control by fungicides was generally similar between plots treated with trinexapac-ethyl and no PGR. In general, mowing frequency did not influence duration of control. Results from this study indicate that paclobutrazol could be used to increase the treatment interval of fungicides and that mowing frequency in the absence of dew is likely to have little influence on fungicide residual efficacy. When used without fungicides, PGRs and less frequent mowing may reduce dollar spot in situations where fungicide use is limited.
\end{abstract}

Dollar spot, incited by Sclerotinia homoeocarpa F.T. Benn., is a persistent foliar disease of many turfgrass species in the United States $(45,46)$. On closely mown turf $(\leq 1.3 \mathrm{~cm})$, dollar spot initially appears as small circular spots generally less than $5 \mathrm{~cm}$ in diameter (40). In severe situations, diseased spots may coalesce and become sunken (40). Dollar spot severity may be reduced by providing turf with adequate nitrogen fertility $(15,27,47)$, displacing leaf wetness $(10,47)$, and the planting of less susceptible cultivars (1). Despite these advances in cultural disease management, the use of fungicides is generally required to maintain acceptable turf quality on golf courses.

The efficacy of fungicides used to control foliar pathogens such as $S$. homoeocarpa depends on several factors. Following application, fungicide efficacy may be reduced due to degradation by light or microbes, volatilization, removal by water, or metabolism by the plant $(31,32,38,39)$. Mowing, a necessary cultural practice for maintaining fine turf, is another factor that likely influences the residual efficacy of fungicides (25). In the northeastern United States, golf course fairways are typically mown 2 to 3 days $^{-1} e^{-1}$

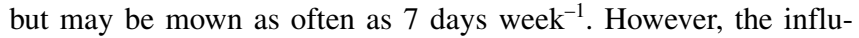
ence of mowing frequency on the removal of treated plant tissue is not well understood.

Mowing wounds leaf tissue and may increase susceptibility to infection by foliar pathogens such as S. homoeocarpa (40). Although more frequent morning mowing has been shown to reduce dollar spot (10), it has been suggested that reducing the period of

Corresponding author: J. E. Kaminski, E-mail: kaminski@ psu.edu

Accepted for publication 22 June 2011.

doi:10.1094/PDIS-04-11-0278

(C) 2011 The American Phytopathological Society leaf wetness from the mowing process is the primary reason for disease suppression $(10,47)$. Interruption of leaf wetness, which is composed of dew and guttation fluid, has long been used as a strategy to manage dollar spot and other turfgrass diseases $(7,10,45,47)$. However, the influence of mowing frequency on disease control in the absence of dew is not known.

In addition to the cultural practices mentioned previously, the use of plant growth regulators (PGRs) is a common practice on golf courses that may influence dollar spot. PGRs are commonly used to reduce mowing requirements or clippings, and may improve the stress tolerance, stand density, color, and competitiveness against weeds of turfgrasses (6). Whereas Golembiewski and Danneberger (15) found that application of trinexapac-ethyl provided a slight reduction in dollar spot severity, most trials have noted little to no reductions in disease by trinexapac-ethyl $(5,26,42,49)$. Applications of paclobutrazol and flurprimidol, two other PGRs commonly used by turfgrass managers, have been shown to result in consistent reductions in dollar spot severity due to their fungistatic effects on $S$. homoeocarpa $(3,11,29,30)$. However, the use of PGRs alone generally does not provide sufficient dollar spot control.

Two approaches have been used to determine the influence of PGRs on dollar spot control with fungicides. In the first approach, studies evaluating the concurrent use of fungicides and PGRs at regular intervals have shown that the inclusion of PGRs provides moderate to no reduction in dollar spot when compared with fungicides alone $(11,29,30,43)$. In the second approach, single disease epidemics following a single fungicide application were examined $(3,43)$. Stewart et al. $(43)$ reported that trinexapac-ethyl had inconsistent influences on the total severity of dollar spot epidemics when applied alone or with chlorothalonil or propiconazole. However, in cases where disease thresholds are very low, duration of disease control is often more important to turfgrass managers than severity because the end users often qualify the presence of disease 
but do not quantify disease levels. In addition to disease severity, Burpee et al. (3) reported duration of control and found that the inclusion of flurprimidol, paclobutrazol, or trinexapac-ethyl generally provided equal or extended control of dollar spot when compared with chlorothalonil, iprodione, propiconazole, or thiophanate-methyl alone.

The aforementioned studies made single fungicide applications or applications at regular intervals but, depending on disease pressure, repeated applications or altering application intervals may be necessary. However, the ability of mowing frequency or PGRs to reduce the number of fungicide applications required to manage dollar spot over a growing season has not been previously evaluated. PGRs and mowing frequency may indirectly influence fungicide residual efficacy due to their influence on the amount of leaf tissue removed during general mowing. In addition, little information is available on the ability of PGRs to reduce disease when combined with other cultural management practices. Therefore, the objectives of this study were to (i) evaluate the influence of mowing frequency and PGRs on dollar spot severity in the absence of fungicides and (ii) determine the potential influence of mowing frequency and PGRs on the duration of dollar spot control provided with fungicides. The working hypotheses for these objectives are (i) less frequent mowing in the absence of dew will reduce dollar spot and (ii) a reduction in the amount of protected tissue removed due to PGR use or less frequent mowing will enhance fungicide residual efficacy.

\section{Materials and Methods}

Four-month field studies were conducted in 2007 and 2008 at the University of Connecticut's Plant Science Research and Education Facility in Storrs, CT. Soil was a Woodbridge (coarse-loamy, mixed, active, mesic Aquic Dystrudepts) sandy loam with a $\mathrm{pH}$ of 6.3 and 7.2 to $8.0 \%$ organic matter. The experiment was designed as a three-by-three-by-five factorial, with three mowing frequencies, three PGR treatments, and five fungicide treatments. Each plot measured 0.91 by $1.83 \mathrm{~m}$ and plots were arranged in a randomized complete block with four replications.

Establishment. In each year, the study was performed on different fields that were prepared similarly. Prior to seeding, a stand of fine-leaf fescue (Festuca sp.) was renovated by applying glyphosate and rototilling several times. 'Putter' creeping bentgrass was seeded at $49 \mathrm{~kg} \mathrm{ha}^{-1}$ in September or October. The site was lightly raked and rolled, then irrigated as needed to promote germination and emergence. The following year, the site was maintained as a typical golf course fairway. Turf was mowed approximately 3 days week $^{-1}$ with a triplex reel mower set to a height of $1.3 \mathrm{~cm}$, and clippings were removed. The study area was irrigated as needed to prevent drought stress. Each study was initiated the following spring, 1.5 years after seeding.

To ensure adequate levels of dollar spot, inoculum was applied on 19 September 2006 to the area to be used in 2007. Inoculum consisted of twice sterilized Kentucky bluegrass (Poa pratensis L.) seed infested with $S$. homoeocarpa isolate 263 ShCT-3, which was obtained from an adjacent field by the authors in 2006. Infested seed was applied to the area with a hand-held shaker jar. Uniform dollar spot symptoms appeared shortly after inoculation and symptoms remained visible in early 2007. Chlorothalonil was applied at a rate of $4.53 \mathrm{~kg}$ a.i. $\mathrm{ha}^{-1}$ on 22 May 2007 to ensure that the area was free from dollar spot symptoms prior to initiation of the study.

The study area used in 2008 was not inoculated and a natural epidemic of dollar spot occurred in 2007. Boscalid and chlorothalonil were applied on 7 August and a final application of chlorothalonil and propiconazole was made on 20 September 2007. In spring 2008, the area was fertilized with $24.4 \mathrm{~kg} \mathrm{~N} \mathrm{ha}^{-1}$ from urea (46-0-0) prior to initiation of the study. Dollar spot symptoms were not visible when the study was initiated.

General study maintenance. Upon beginning the study each year, two practices were initiated as part of a cultural program to reduce dollar spot. First, dissolved urea (46-0-0) was applied approximately every 14 days to the entire study site at a rate of $9.8 \mathrm{~kg}$
$\mathrm{N} \mathrm{ha}^{-1}$. The study area was irrigated immediately following fertilizer applications with approximately $3 \mathrm{~mm}$ of water. Second, dew was displaced daily between 0700 and $0900 \mathrm{~h}$ by dragging a waterfilled rubber hose across all plots. Dew was not displaced when rain occurred during this time period. In addition to contributing to the cultural program, dew displacement served to minimize the confounding influence of dew among mowing frequency treatments.

Treatments. Mowing treatments consisted of turf mowed 2, 4, or 6 days week ${ }^{-1}$. The 2 -day-week ${ }^{-1}$ treatments were mowed on Sunday and Thursday; 4-day-week ${ }^{-1}$ treatments on Sunday, Tuesday, Thursday, and Saturday; and 6-day-week ${ }^{-1}$ treatments on each day except Wednesday. All plots were mowed to a height of $1.3 \mathrm{~cm}$ with a Jacobsen PGM 22 (Textron, Incorporated, Providence, RI) 55.9-cm-wide walk-behind reel mower, and clippings were removed. Mowing was performed after the foliage had sufficient time to fully dry following dew displacement. Mowing treatments were occasionally performed during light rain events or when weather conditions prevented foliage from completely drying after dew displacement. Mowing treatments were not performed on 5 days in 2007 and on 6 days in 2008 due to saturated soil or because clipping collection had been delayed due to rain.

Paclobutrazol (Trimmit 2SC; Syngenta Crop Protection, Greensboro, NC) and trinexapac-ethyl (Primo MAXX 1EC; Syngenta Crop Protection) were applied approximately every 21 days at a rate of 0.280 and $0.096 \mathrm{~kg}$ a.i. $\mathrm{ha}^{-1}$, respectively. The third treatment consisted of a nontreated control. All PGR applications were made to dry foliage after daily mowing treatments had been performed. Trinexapac-ethyl was allowed to dry on the foliage because it is foliar absorbed, and paclobutrazol was watered-in with 3 $\mathrm{mm}$ of water within $24 \mathrm{~h}$ of application because paclobutrazol is root absorbed.

Four fungicides with varying modes of activity and a nontreated control were selected. All fungicides were applied at low label rates in an effort to evaluate the potential reduction of pesticides needed to suppress dollar spot over the entire study. The contact fungicide chlorothalonil (Daconil Ultrex 82.5WDG; Syngenta Crop Protection) was applied at $4.53 \mathrm{~kg}$ a.i. $\mathrm{ha}^{-1}$. The localized penetrant iprodione (Chipco 26GT; Bayer Environmental Science, Research Triangle Park, NC) was applied at $1.53 \mathrm{~kg}$ a.i. ha ${ }^{-1}$. The acropetal penetrants boscalid (Emerald 70WG; BASF Corporation, Research Triangle Park, NC) and propiconazole (Banner MAXX 1.3EC; Syngenta Crop Protection) were applied at 0.28 and 0.50 $\mathrm{kg}$ a.i. $\mathrm{ha}^{-1}$, respectively.

All fungicide and PGR treatments were applied with a $\mathrm{CO}_{2}$ pressurized $(276 \mathrm{kPa})$ backpack sprayer calibrated to deliver water at 407 liters $\mathrm{ha}^{-1}$ using a metronome to regulate walking speed. All treatments were applied using a single flat-fan air-induction nozzle (AI9504E), which has previously been shown to provide excellent suppression of dollar spot (19) while minimizing the potential for drift.

The date of initial application for all fungicides in 2007 (1 June) was when active dollar spot was first observed in the study area but, in 2008, the application date (30 May) was based on dollar spot activity in adjacent fields. To determine the timing of subsequent applications or reapplications, dollar spot was assessed daily by counting the number of dollar spot infection centers plot $^{-1}$. Individual fungicide treatments were reapplied to all replicate plots when the mean number of infection centers exceeded a threshold that was deemed commercially unacceptable ( 5 infection centers plot $^{-1}$ and 3 infection centers $\mathrm{m}^{-2}$ ). Unexpectedly, some treatments did not fully recover (defined as having $<4$ infection centers plot $^{-1}$ ) before disease activity resumed. Therefore, in addition to the above threshold, three subjective reapplication thresholds were established during the study. The three reapplication thresholds for plots that did not fully recover were if the mean number of infection centers across replicates increased (i) on two consecutive days, (ii) by $\geq 50 \%$ from the previous day, or (iii) after declining for three consecutive days. The minimum reapplication interval for all thresholds was set at 7 days due to label restrictions. Fungicide 
treatments were applied between 1100 and $2000 \mathrm{~h}$ and after daily mowing treatments were performed.

In 2007, mowing treatments were initiated on 1 June and continued until 28 September, PGRs were applied on 1 and 23 June, 13 July, 2 and 23 August, and 14 September, and fertilizer applications were made on 15 June, 3 and 20 July, 3 and 17 August, and 3 and 24 September. In 2008, mowing treatments began on 30 May and ended on 1 October. PGRs were applied on 30 May, 20 June, 11 July, 1 and 23 August, and 16 September, and fertilizer was applied on 13 and 26 June, 11 and 26 July, 9 and 22 August, and 5 September. In each year, seven urea applications were made during the season for a total of $68 \mathrm{~kg} \mathrm{~N} \mathrm{ha}^{-1}$.

Data collection and statistical analyses. Disease severity was assessed weekly by visually estimating the percent plot area blighted by $S$. homoeocarpa on a linear 0 -to- $100 \%$ scale, where 0 $=$ entire plot area void of dollar spot and $100=$ entire plot area exhibiting dollar spot symptoms. The area under the disease progress curve (AUDPC) was determined for infection center and plot area blighted data according to the formula $\Sigma\left\{\left[\left(y_{i}+y_{i+1}\right) / 2\right]\left(t_{i+1}-\right.\right.$ $\left.\left.t_{i}\right)\right\}$, where $i=1,2,3, \ldots, n-1$ and $y_{i}$ is the amount of disease (infection centers or plot area blighted) at the time $t_{i}$ (in days) of the $i$ th rating (4). Data were examined to determine whether transformation was necessary prior to analysis. Data were subjected to analysis of variance in the Mixed Model procedure in SAS (v 9.2; SAS Institute, Inc., Cary, NC) to determine main factor and interactive effects. To determine whether infection center data from both years could be combined, AUDPC data were standardized by dividing values with the length of the observation period in each year (4), and year was included as a fixed effect in the analysis of variance. Combining disease severity data from both years was evaluated by including year as a fixed effect in analysis of variance of plot area blighted data. The direct influence of mowing frequency and PGRs within plots not treated with fungicides was determined from plot area blighted data with CONTRAST statements in the Mixed Model procedure. Any statistically significant effects were examined by separating means using Fisher's protected least significant difference $t$ test at $P \leq 0.05$.

Although the decision to reapply a fungicide was based on mean number of infection centers across replicate plots to simplify the experiment, analyzing only application interval data ignores the intratreatment variability in duration of control that was observed among replicate plots. Therefore, for the sole purpose of data analysis, duration of control was determined for each replicate plot of each fungicide treatment. The restriction of 7 days since last application was not applied to duration of control. For plots experiencing acceptable recovery $(<4$ infection centers), disease control was determined to have failed if the number of infection centers exceeded 5 after recovery. In cases when disease pressure was high and turf did not fully recover from damage, two additional thresholds were used to determine failure of control in individual plots. The two thresholds were if the number of infection centers (i) increased on two consecutive days or (ii) increased $>50 \%$ of the count from the previous day. The 10th percentile of observed duration of control values was calculated as a summary statistic that represents the minimum duration of control that can be reasonably expected under most conditions.

During the course of the study, it was common for at least one of four replicate plots to not experience control failure by the date of fungicide reapplication. To analyze data in this study using analysis of variance or parametric regression, this subset of the data would have to be removed or modified, thus introducing significant bias into the results $(2,16)$. Instead, the application interval data in this study was considered as time-to-event data, with the event defined as disease control failure. Survival analysis was designed for time-to-event data and incorporated methods to account for "censored" cases in which the event of interest does not occur in the observation period for some subjects $(2,16,21)$. In this study, plots that did not experience failure by the time of fungicide application were marked as censored. The benefits and applications of survival analysis in plant disease epidemiology have been reviewed by Scherm and Ojiambo (37).

Statistical analyses of AUDPC values for infection center data were used to identify factors to be evaluated using survival analysis. Any significant main or interactive effects were further evaluated by obtaining Kaplan-Meier (20) estimates of survival functions and mean duration of control values using the Lifetest procedure in SAS. The influence of these effects on survival functions was evaluated with the log-rank test. Within significant effects, individual survival curves were separated with multiple logrank comparisons that were subjected to Tukey's adjustment to reduce the overall type I error rate.

\section{Results}

Disease progress. In 2007, active dollar spot infection centers were first observed in the study area on 1 June, and disease pressure was considered extremely severe in June and July. Based on evaluation of plot area blighted in plots not treated with a fungicide or PGR, peak dollar spot symptoms occurred in early August. On 10 August, plots not treated with PGRs or fungicides contained an average of $58 \%$ plot area blighted (Fig. 1). Turf recovery occurred between mid-August and September and nontreated plots exhibited an average of $8.2 \%$ damage from $S$. homoeocarpa on the final rating date (28 September).

In 2008, active dollar spot symptoms were first noted in the study area on 10 June but, in June and July, disease pressure was low compared with 2007. On 1 August, nontreated plots contained less than 3\% plot area blighted. Disease activity increased in midAugust and September and peaked on the final rating date (1 October), with plots not treated with a fungicide or PGR reaching an average of $32 \%$ plot area blighted.

Dollar spot severity: 2007. Due to the presence of significant interactions among year, mowing frequency, and PGRs, data from

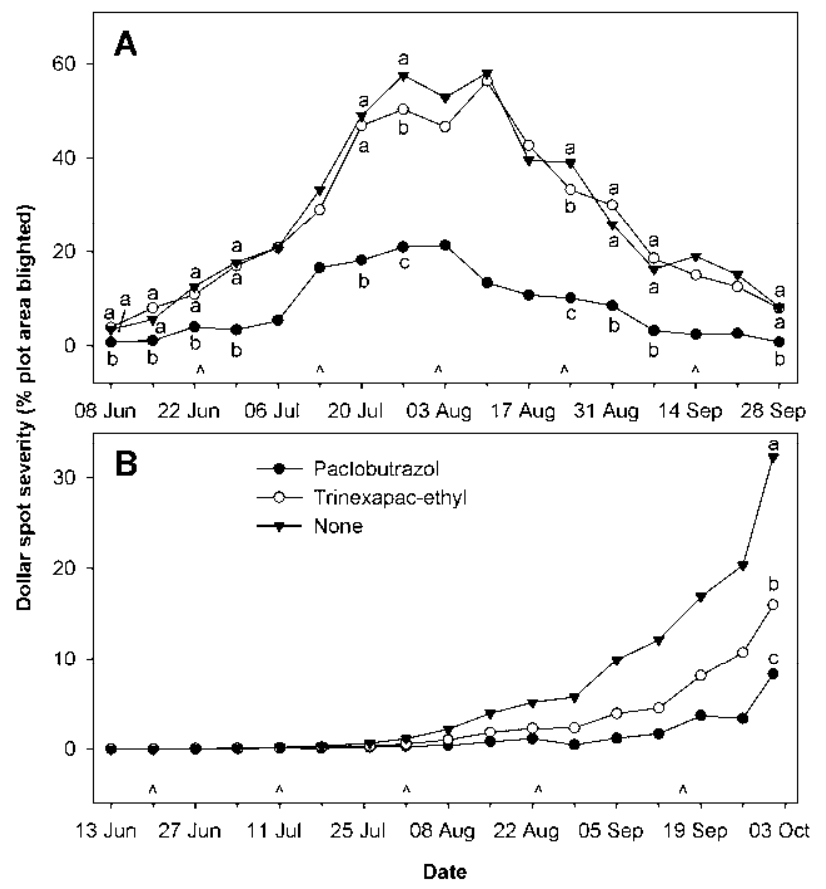

Fig. 1. Dollar spot severity on fairway-height 'Putter' creeping bentgrass in A, 2007 and B, 2008 as influenced by the plant growth regulators (PGRs) paclobutrazol or trinexapac-ethyl in the absence of fungicides. PGRs were applied $\left({ }^{\wedge}\right)$ at approximately 21-day intervals. Percentage of plot area affected by Sclerotinia homoeocarpa was visually estimated on a linear 0-to-100 scale, where $0=$ entire plot healthy and $100=$ entire plot exhibiting dollar spot symptoms. Data points represent means of PGRs averaged across mowing frequency treatments. Within a rating date, means associated with the same letter are not significantly different according to Fisher's protected least significant difference $t$ test at $P \leq 0.05$. Letter absence indicates that the mowing frequency-PGR interaction was significant on that date. Data were square-root transformed prior to analysis but actual means are shown. 
each year were analyzed separately. Disease severity data were square-root transformed prior to analysis to alleviate deviations from assumptions of parametric analyses. Dollar spot severity (averaged across mowing frequency treatments) was reduced in plots treated with paclobutrazol on 10 of the 17 rating dates in 2007, when compared with plots treated with trinexapac-ethyl or not treated with a PGR (Fig. 1). The range of suppression was 63

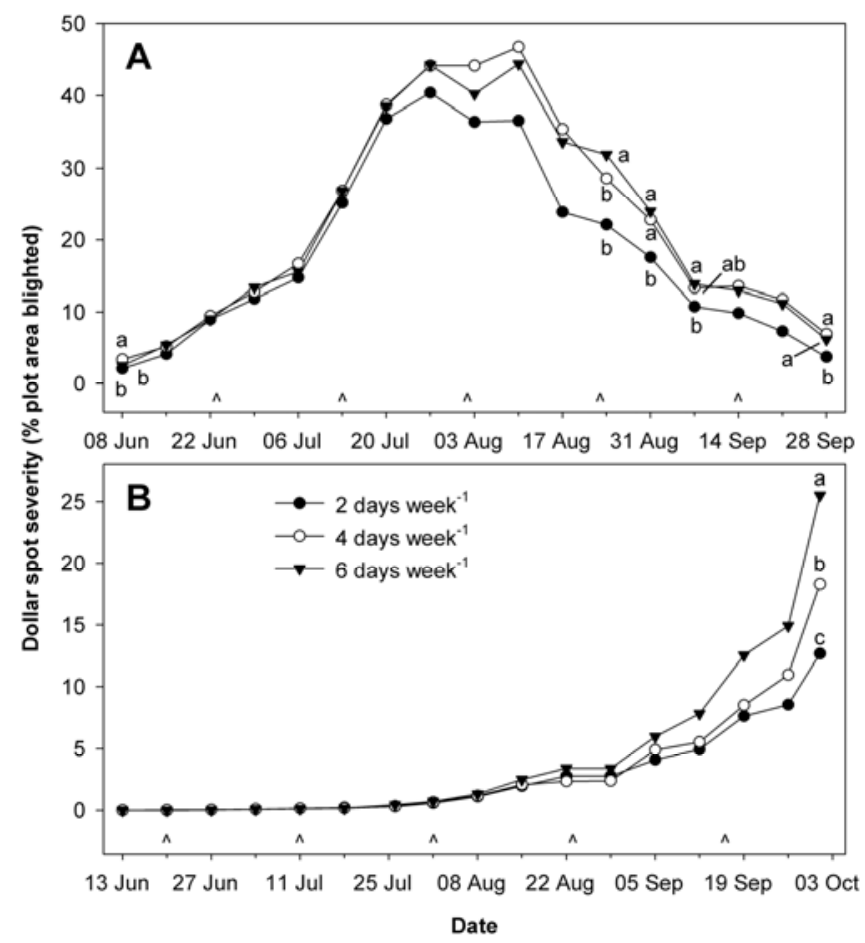

Fig. 2. Dollar spot severity on fairway-height 'Putter' creeping bentgrass in A, 2007 and $\mathbf{B}, 2008$ as influenced by mowing frequency in the absence of fungicides. Plots were mown 2,4 , or 6 days week ${ }^{-1}$ with a walk-behind reel mower set to a height of $1.3 \mathrm{~cm}$. Percentage of plot area affected by Sclerotinia homoeocarpa was visually estimated on a linear 0-to-100 scale, where $0=$ entire plot healthy and $100=$ entire plot exhibiting dollar spot symptoms. Data points represent means of mowing frequencies averaged across plant growth regulator (PGR) treatments applied $\left({ }^{\wedge}\right)$ at approximately 21-day intervals. Within a rating date, means associated with the same letter are not significantly different according to Fisher's protected least significant difference $t$ test at $P \leq 0.05$. Letter absence on a given date indicates lack of a significant mowing frequency effect or the presence of a significant mowing frequency-PGR interaction. Data were square-root transformed prior to analysis but actual means are shown. to $90 \%$ compared with plots not receiving a PGR. On two dates, dollar spot was reduced by 13 to $15 \%$ in plots treated with trinexapac-ethyl when compared with nontreated turf. When averaged across PGRs, mowing frequency significantly impacted dollar spot severity on five dates (Fig. 2). In late August and September, dollar spot was reduced by 23 to $31 \%$ in plots mown 2 days week $^{-1}$ when compared with turf mown 6 days week ${ }^{-1}$.

A significant mowing frequency-PGR interaction was observed on seven dates and for AUDPC values of plot area blighted data in 2007 (Fig. 1). On these dates, the effect of mowing frequency was examined separately within each PGR. Dollar spot was reduced on seven dates in plots receiving trinexapac-ethyl that were mown 2 days week ${ }^{-1}$ when compared with those mown 4 and/or 6 days week $^{-1}$ (Table 1). In plots treated with paclobutrazol, dollar spot was reduced on three dates in plots mown 2 days week $^{-1}$, when compared with those mown 6 days week $^{-1}$. Except for 14 September, dollar spot severity was similar among mowing frequencies in plots not receiving a PGR. AUDPC values were reduced by $29 \%$ in plots treated with trinexapac-ethyl that were mown 2 days week $^{-1}$ when compared with those mown 6 days week $^{-1}$. AUDPC values among mowing treatments were similar for plots receiving paclobutrazol or no PGR.

Dollar spot severity: 2008. On the final rating date in 2008, dollar spot was reduced by 74 and $51 \%$ in plots treated with paclobutrazol and trinexapac-ethyl, respectively, when compared with nontreated turf (Fig. 1). Although significant differences existed on select earlier dates (unpublished data), these differences were likely of little agronomic importance because disease severity was low $(\leq 0.6 \%)$. In all of these cases, however, paclobutrazol resulted in less dollar spot when compared with nontreated plots. The main effect of mowing on dollar spot severity was significant only on the final rating date (1 October) (Fig. 2). On this date, dollar spot severity was reduced by 50 or $28 \%$ in plots mown 2 or 4 days week ${ }^{-1}$, respectively, when compared with turf mown 6 days week $^{-1}$.

A significant interaction between mowing frequency and PGR was observed on 11 rating dates and for AUDPC values of plot area blighted data in 2008 (Fig. 1). Among plots receiving trinexapac-ethyl, dollar spot was reduced on seven dates in August and September in plots mown 2 days week ${ }^{-1}$ when compared with those mown 6 days week $^{-1}$ (Table 2). The reduction in disease severity in plots mown 2 days week ${ }^{-1}$ was observed on three dates in paclobutrazol-treated turf. AUDPC values were reduced by 60 to $61 \%$ in plots receiving paclobutrazol or trinexapac-ethyl that were mown 2 days week $^{-1}$ when compared with those mown 6 days week $^{-1}$. Among plots not receiving a PGR, dollar spot was reduced on three or five rating dates in August and September in plots

Table 1. Interaction between mowing frequency (MF) and plant growth regulators (PGRs) on dollar spot on fairway-height 'Putter' creeping bentgrass, 2007

\begin{tabular}{|c|c|c|c|c|c|c|c|c|}
\hline \multirow[b]{2}{*}{ PGR, MFy } & \multicolumn{7}{|c|}{ Dollar spot (plot area blighted) $(\%)^{x}$} & \multirow[b]{2}{*}{$\operatorname{AUDPC}(\% \text {-weeks })^{x}$} \\
\hline & 6 July & 13 July & 3 August & 10 August & 17 August & 14 September & 21 September & \\
\hline \multicolumn{9}{|l|}{$\mathrm{PB}$} \\
\hline 2 & 6.3 & 17.0 & 21.3 & 11.8 & $7.9 \mathrm{~b}$ & $1.3 \mathrm{~b}$ & $0.5 \mathrm{~b}$ & 925 \\
\hline 4 & 5.0 & 15.3 & 20.5 & 12.8 & $9.8 \mathrm{ab}$ & $0.8 \mathrm{~b}$ & $1.6 \mathrm{~b}$ & 893 \\
\hline 6 & 4.8 & 17.3 & 22.3 & 15.5 & $14.5 \mathrm{a}$ & $5.2 \mathrm{a}$ & $5.8 \mathrm{a}$ & 1,169 \\
\hline \multicolumn{9}{|l|}{$\mathrm{TE}$} \\
\hline 2 & $17.3 \mathrm{~b}$ & $23.8 \mathrm{~b}$ & $34.3 \mathrm{c}$ & $42.3 \mathrm{~b}$ & $28.3 \mathrm{~b}$ & $11.5 \mathrm{~b}$ & $8.8 \mathrm{~b}$ & $2,384 \mathrm{~b}$ \\
\hline 4 & $24.5 \mathrm{a}$ & $30.0 \mathrm{a}$ & $59.5 \mathrm{a}$ & $69.3 \mathrm{a}$ & $54.5 \mathrm{a}$ & $16.8 \mathrm{a}$ & $16.8 \mathrm{a}$ & $3,588 \mathrm{a}$ \\
\hline 6 & $20.8 \mathrm{ab}$ & $33.3 \mathrm{a}$ & $46.3 \mathrm{~b}$ & $57.5 \mathrm{a}$ & $45.3 \mathrm{a}$ & $16.8 \mathrm{a}$ & $12.0 \mathrm{~b}$ & $3,350 \mathrm{a}$ \\
\hline \multicolumn{9}{|l|}{ None } \\
\hline 2 & 20.8 & 34.8 & 53.8 & 55.8 & 35.5 & $16.8 \mathrm{~b}$ & 12.8 & 3,190 \\
\hline 4 & 20.5 & 35.3 & 52.5 & 58.3 & 42.0 & $23.3 \mathrm{a}$ & 16.8 & 3,402 \\
\hline 6 & 21.3 & 30.0 & 52.3 & 60.3 & 41.3 & $17.0 \mathrm{~b}$ & 15.8 & 3,245 \\
\hline
\end{tabular}

${ }^{\mathrm{x}}$ Percentage of plot area affected by Sclerotinia homoeocarpa was visually estimated on a linear 0-to-100 scale, where $0=$ entire plot healthy and $100=$ entire plot exhibiting dollar spot symptoms. Within each PGR, means in a column followed by the same letter are not significantly different according to Fisher's protected least significant different $t$ test at $P \leq 0.05$. Absence of letters indicates a lack of significance for that PGR. Data were square-root transformed prior to analysis, but actual means are shown.

y PGR treatments included paclobutrazol (PB) and trinexapac-ethyl (TE) applied on 1 and 23 June, 13 July, 2 and 13 August, and 14 September, and a nontreated control. Mowing treatments consisted of plots mown 2, 4, or 6 days week ${ }^{-1}$.

${ }^{\mathrm{z}}$ AUDPC $=$ area under the disease progress curve. 
mown 2 or 4 days week ${ }^{-1}$, respectively, when compared with turf mown 6 days week ${ }^{-1}$. However, AUDPC values were significantly lower only in plots mown 4 days week $^{-1}$.

Duration of control: 2007. Due to the presence of a significant year-fungicide interaction $(P=0.0013)$, years were analyzed separately. Analysis of variance on AUDPC data in 2007 revealed that only the main effects of PGR and fungicides were significant (Table 3). Among PGRs, AUDPC values were lowest in plots treated with paclobutrazol, and values between plots treated with trinexapac-ethyl or not receiving a PGR were similar (Fig. 3B). Duration of control was significantly $(P<0.0001)$ influenced by the main effects of PGR and fungicide (Table 4). Plots treated with paclobutrazol extended dollar spot suppression by approximately 11 days when compared with turf treated with trinexapac-ethyl or no PGR.

Four applications of boscalid or propiconazole and six of iprodione were required in 2007 to control dollar spot when used in combination with trinexapac-ethyl or no PGR (unpublished data). When combined with paclobutrazol, the number of fungicide applications was reduced by one. When used in combination with paclobutrazol, only five to six applications of chlorothalonil were applied over the study. In total, however, 9 to 10 applications of chlorothalonil were required when used in a program with trinexapac-ethyl or without a PGR. Under the extreme disease pressure observed in 2007, dollar spot levels were generally unacceptable ( $>5$ infection centers plot $^{-1}$ ) in plots treated with chlorothalonil and, to a lesser extent, in those treated with iprodione (unpublished data). With respect to mowing frequency, one fewer application of iprodione was needed in plots treated with paclobutrazol that were mowed 2 days week $^{-1}$ when compared with those mowed 4 or 6 days week ${ }^{-1}$. For chlorothalonil, one fewer application was required in plots mowed 2 days week $^{-1}$ when compared with those mowed 6 days week ${ }^{-1}$, regardless of PGR. Due to these differences in the number of required applications, additional survival analyses were performed to determine the influence of mowing frequency on duration of control by chlorothalonil and iprodione. Although estimated duration of control values for iprodione were numerically highest in turf mowed 2 days week $^{-1}$, a significant difference was observed only between plots mowed 2 or 4 days week ${ }^{-1}$ (Table 5). For chlorothalonil, survival curves of mowing frequency treatments were statistically similar $(P=$ 0.5805). Mowing frequency did not influence control by boscalid or propiconazole (unpublished data).

Duration of control: 2008. Fungicides were last applied on 11 September and monitored until all treatments had exceeded one of the fungicide reapplication thresholds. A significant interaction between fungicides and PGRs was observed in 2008 for AUDPC data (Table 3), and the influence of PGRs was evaluated within each fungicide. In plots treated with boscalid (Fig. 4A), AUDPC values were significantly lower for trinexapac-ethyl when compared with turf not receiving a PGR, but values for paclobutrazol were statistically similar to these two treatments. For iprodione (Fig. 4C), AUDPC values were significantly lower (by 41 to $52 \%$ ) in plots receiving paclobutrazol when compared with plots receiv-

Table 2. Interaction between mowing frequency (MF) and plant growth regulators (PGRs) on dollar spot in fairway-height 'Putter' creeping bentgrass, 2008

\begin{tabular}{|c|c|c|c|c|c|c|c|c|c|}
\hline \multirow[b]{2}{*}{ PGR, MF ${ }^{y}$} & \multicolumn{8}{|c|}{ Dollar spot (plot area blighted) $(\%)^{\mathrm{x}}$} & \multirow[b]{2}{*}{$\operatorname{AUDPC}(\% \text { weeks })^{\mathrm{z}}$} \\
\hline & 8 August & 15 August & 22 August & 29 August & 5 September & 12 September & 19 September & 26 September & \\
\hline \multicolumn{10}{|l|}{$\overline{\mathrm{PB}}$} \\
\hline 2 & 0.3 & 0.4 & $0.5 \mathrm{~b}$ & 0.3 & 0.7 & 0.9 & $2.2 \mathrm{~b}$ & $2.3 \mathrm{~b}$ & $64 \mathrm{~b}$ \\
\hline 4 & 0.3 & 0.8 & $1.0 \mathrm{~b}$ & 0.5 & 1.2 & 1.7 & $3.2 \mathrm{~b}$ & $2.8 \mathrm{ab}$ & $101 \mathrm{ab}$ \\
\hline 6 & 0.6 & 1.1 & $1.9 \mathrm{a}$ & 0.7 & 1.7 & 2.4 & $5.6 \mathrm{a}$ & $5.0 \mathrm{a}$ & $165 \mathrm{a}$ \\
\hline \multicolumn{10}{|l|}{ TE } \\
\hline 2 & $0.4 \mathrm{~b}$ & $0.8 \mathrm{~b}$ & $1.1 \mathrm{~b}$ & $0.9 \mathrm{~b}$ & $1.4 \mathrm{~b}$ & $2.0 \mathrm{~b}$ & $4.1 \mathrm{~b}$ & $6.0 \mathrm{~b}$ & $137 \mathrm{~b}$ \\
\hline 4 & $1.7 \mathrm{a}$ & $2.7 \mathrm{a}$ & $3.2 \mathrm{a}$ & $3.2 \mathrm{a}$ & $5.6 \mathrm{a}$ & $6.0 \mathrm{a}$ & $9.8 \mathrm{a}$ & $13.6 \mathrm{a}$ & $364 a$ \\
\hline 6 & $1.0 \mathrm{ab}$ & $2.0 \mathrm{a}$ & $2.6 \mathrm{a}$ & $2.9 \mathrm{a}$ & $4.7 \mathrm{a}$ & $5.6 \mathrm{a}$ & $10.5 \mathrm{a}$ & $12.5 \mathrm{a}$ & $342 \mathrm{a}$ \\
\hline \multicolumn{10}{|l|}{ None } \\
\hline 2 & 2.7 & 4.7 & $6.7 \mathrm{a}$ & $7.1 \mathrm{a}$ & 10.2 & $12.0 \mathrm{~b}$ & $16.6 \mathrm{~b}$ & $17.4 \mathrm{~b}$ & $607 \mathrm{ab}$ \\
\hline 4 & 1.5 & 2.7 & $3.0 \mathrm{~b}$ & $3.5 \mathrm{~b}$ & 7.9 & $8.9 \mathrm{~b}$ & $12.6 \mathrm{~b}$ & $16.5 \mathrm{~b}$ & $464 \mathrm{~b}$ \\
\hline 6 & 2.4 & 4.4 & $5.8 \mathrm{a}$ & $6.6 \mathrm{a}$ & 11.5 & $15.5 \mathrm{a}$ & $21.5 \mathrm{a}$ & $27.3 \mathrm{a}$ & $761 \mathrm{a}$ \\
\hline
\end{tabular}

${ }^{x}$ Percentage of plot area affected by Sclerotinia homoeocarpa was visually estimated on a linear 0-to-100 scale, where $0=$ entire plot healthy and $100=$ entire plot exhibiting dollar spot symptoms. Within each PGR, means in a column followed by the same letter are not significantly different according to Fisher's protected least significant different $t$ test at $P \leq 0.05$. Absence of letters indicates a lack of significance for that PGR. Data were square-root transformed prior to analysis, but actual means are shown.

${ }^{\text {y }}$ PGR treatments included paclobutrazol (PB) and trinexapac-ethyl (TE) applied on 30 May, 20 June, 11 July, 1 and 23 August, and 16 September, and a nontreated control. Mowing treatments consisted of plots mown 2, 4, or 6 days week ${ }^{-1}$.

${ }^{\mathrm{z}} \mathrm{AUDPC}=$ area under the disease progress curve.

Table 3. Seasonal daily dollar spot levels on a 'Putter' creeping bentgrass fairway as influenced by mowing frequency (MF), plant growth regulators (PGRs), and various fungicides

\begin{tabular}{|c|c|c|c|c|c|}
\hline \multirow[b]{3}{*}{ Source of variation } & \multirow[b]{3}{*}{ df } & \multicolumn{4}{|c|}{ AUDPC (IC-days)w } \\
\hline & & \multicolumn{2}{|c|}{2007} & \multicolumn{2}{|c|}{2008} \\
\hline & & $\boldsymbol{F}$ & $P \geq F$ & $\boldsymbol{F}$ & $P \geq F$ \\
\hline $\mathrm{MF}^{\mathrm{x}}$ & 2 & 0.46 & 0.6337 & 0.30 & 0.7385 \\
\hline $\mathrm{PGR}^{\mathrm{y}}$ & 2 & 9.94 & 0.0001 & 4.98 & 0.0085 \\
\hline Fungicide $^{\mathrm{z}}$ & 3 & 23.28 & $<0.0001$ & 7.29 & 0.0002 \\
\hline $\mathrm{MF} \times \mathrm{PGR}$ & 4 & 0.15 & 0.9610 & 0.48 & 0.7513 \\
\hline $\mathrm{MF} \times$ fungicide & 6 & 1.43 & 0.2109 & 1.04 & 0.4062 \\
\hline PGR $\times$ fungicide & 6 & 0.86 & 0.5285 & 2.31 & 0.0390 \\
\hline $\mathrm{MF} \times \mathrm{PGR} \times$ fungicide & 12 & 0.45 & 0.9404 & 0.98 & 0.4754 \\
\hline
\end{tabular}

${ }^{\mathrm{w}}$ Area under the disease progress curve (AUDPC) values were determined from daily counts of the number of dollar spot infection centers (ICs) plot ${ }^{-1}$.

${ }^{x}$ Mowing treatments consisted of plots mowed 2, 4, or 6 days week ${ }^{-1}$.

y PGRs paclobutrazol and trinexapac-ethyl were applied at approximately 21-day intervals.

${ }^{\mathrm{z}}$ Fungicide treatments included boscalid, chlorothalonil, iprodione, and propiconazole. Treatments were initiated on 1 June 2007 and 30 May 2008 and were reapplied when dollar spot exceeded the threshold of five infection centers plot ${ }^{-1}$. The study was terminated on 28 September 2007 and 1 October 2008. 
ing trinexapac-ethyl or no PGR. A similar numeric trend was observed for the remaining fungicides but AUDPC values were not significantly influenced by PGRs in plots receiving chlorothalonil ( $P=0.0566$; Fig. 4B) or propiconazole $(P=0.3868$; Fig. 4D).

Due to the interaction for total disease data discussed above, survival analyses were performed to determine the influence of PGRs on duration of control for each fungicide separately (Table 6). For boscalid, chlorothalonil, and iprodione, values of estimated duration of control for plots treated with paclobutrazol or trinexapacethyl were significantly higher than or statistically similar to, respectively, those in turf not treated with a PGR. Survival curves for trinexapac-ethyl were statistically similar to curves for paclobutrazol in plots treated with boscalid or iprodione. Survival analysis indicated no differences among PGRs in plots treated with propiconazole. Although the number of chlorothalonil and iprodione applications made in 2008 varied among mowing treatments, mowing frequency did not significantly extend estimated duration of control for any fungicide and trends among treatments were not consistent (unpublished data).

In both study years, estimated survival functions for chlorothalonil and iprodione declined steeply between 10 and 20 days after application, whereas declines for boscalid and propiconazole were more gradual (Figs. 3 and 4). However, curve shape differed between study years. Boscalid and propiconazole provided approximately 21 days of control in 2007, with few exceptions, but shorter durations of control were observed in 2008. This difference is reflected in the lower $\mathrm{P}_{10}$ values in 2008 compared with 2007. While exhibiting control failures sooner, curves in 2008 had a longer tail when compared with 2007, with a maximum of 83 and 53 days, respectively. Duration of control was generally inversely proportional to overall disease pressure in both study years. The aforementioned differences in curve shape between study years were also observed for PGR survival curves.

\section{Discussion}

This study demonstrates that PGR use combined with less frequent mowing can reduce dollar spot, thus providing additional cultural options for dollar spot management in cases where fungicide use is restricted. Despite the reduction in dollar spot severity

Table 4. Duration of control of various fungicides as a main effect and as influenced by various plant growth regulators (PGRs) on a 'Putter' creeping bentgrass fairway at the University of Connecticut in 2007

\begin{tabular}{lrrcc}
\hline & \multicolumn{4}{c}{ Survival analysis (days) $^{\mathbf{x}}$} \\
\cline { 2 - 5 } Effect $^{\mathbf{y}}$ & $\boldsymbol{n}$ & $\mathbf{P}_{\mathbf{1 0}}$ & DOC $_{\mathbf{E}}$ & $\boldsymbol{P}>\boldsymbol{\chi}^{\mathbf{2} \mathbf{z}}$ \\
\hline Fungicide & & & & $<0.0001$ \\
$\quad$ Boscalid & 96 & 21.0 & $34.3 \mathrm{a}$ & $\ldots$ \\
Chlorothalonil & 242 & 9.0 & $15.9 \mathrm{c}$ & $\ldots$ \\
Iprodione & 160 & 12.0 & $20.9 \mathrm{~b}$ & $\ldots$ \\
Propiconazole & 96 & 22.0 & $37.0 \mathrm{a}$ & $\ldots$ \\
PGR & & & & $<0.0001$ \\
PB & 140 & 14.0 & $33.0 \mathrm{a}$ & $\ldots$ \\
TE & 222 & 10.0 & $22.2 \mathrm{~b}$ & $\ldots$ \\
None & 232 & 10.0 & $21.4 \mathrm{~b}$ & $\ldots$ \\
\hline
\end{tabular}

x Abbreviations: $n=$ the number of duration of control intervals used in analyses; $\mathrm{P}_{10}=$ the 10th percentile for duration of control was determined across remaining factors; $\mathrm{DOC}_{\mathrm{E}}=$ estimates of mean duration of control determined from Kaplan-Meier survival curves. Within each effect, $\mathrm{DOC}_{\mathrm{E}}$ values followed by the same letter are not significantly different at $P \leq$ 0.05 according to Tukey's adjustment of multiple log-rank comparisons of survival curves.

${ }^{y}$ Fungicide treatments were initiated on 1 June 2007 and were reapplied when dollar spot exceeded a threshold of five infection centers plot $^{-1}$. PGRs paclobutrazol (PB) and trinexapac-ethyl (TE) were applied at approximately 21 -day intervals.

${ }^{\mathrm{z}}$ Main effects were evaluated for significance at $P \leq 0.05$ by the log-rank test for homogeneity of treatment survival curves when considered across remaining factors.

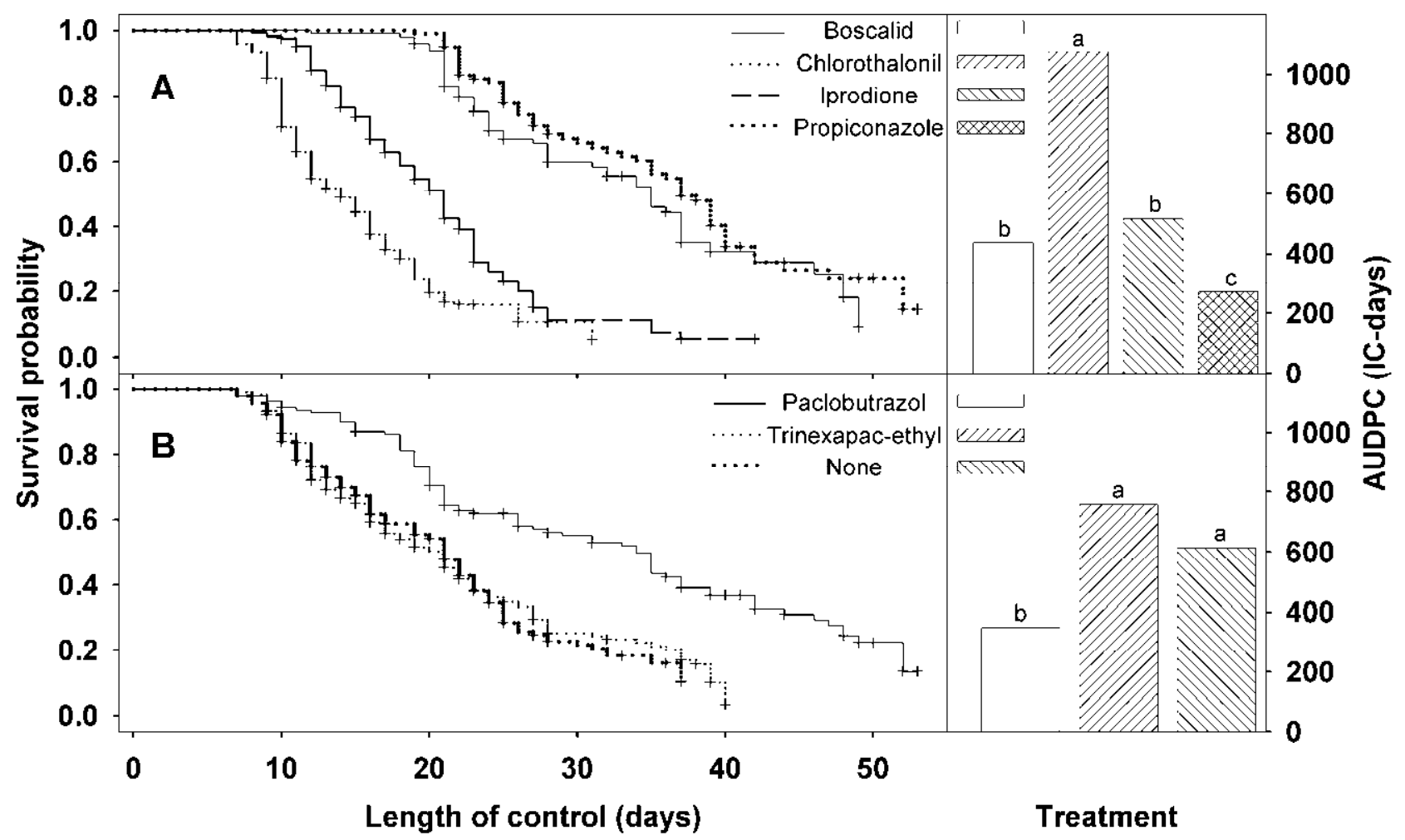

Fig. 3. Left panels: Kaplan-Meier estimates of survival functions describing duration of dollar spot control of $\mathbf{A}$, various fungicides when considered as a main effect or as influenced by B, plant growth regulators in 2007. Censored observations (+) occurred when control in an individual plot had not failed when the fungicide treatment was reapplied. Right panels: area under the disease progress curve (AUDPC) values determined from daily assessment of the number of dollar spot infection centers plot ${ }^{-1}$. The AUDPC data were subjected to an analysis of variance, and bars with the same letter are not significantly different according to Fisher's protected least significant difference $t$ test at $P \leq 0.05$. AUDPC data were $\log _{10}$ transformed prior to analysis but actual means are shown. Plant growth regulators were applied at approximately 21 -day intervals, but fungicides were reapplied only after control from the previous application failed based on mean disease values exceeding five infection centers plot ${ }^{-1}$. 
by trinexapac-ethyl and reduced mowing frequency in the absence of fungicides, these practices are not likely to offer a practical benefit to the residual efficacy of fungicides for dollar spot control. Regular use of paclobutrazol, however, may substitute for some fungicide sprays by extending intervals between fungicide applications. However, paclobutrazol should be used with caution due to its unclear contribution to the development of demethylation-inhibitor (DMI)-resistant populations of $S$. homoeocarpa.

Data from this study provide support for the traditional assumption that mowing injury influences the susceptibility of turf to infection by foliar pathogens such as $S$. homoeocarpa due to the availability of infection courts (40). S. homoeocarpa has been shown to be more aggressive on cut compared with intact leaves (34); thus, disease in our study was likely influenced by the frequency of injury. In addition to directly impacting infection, increased mowing frequencies may have negative influences on host physiology and reduce the defense of turfgrasses against foliar pathogens like $S$. homoeocarpa $(9,17,24)$. Although more frequent morning mowing was previously reported to decrease dollar spot severity (10), results from this study suggest that increased frequency of injury may mitigate the benefit to dollar spot control afforded by displacing dew more often. Studies that compared mowing with other methods of dew displacement have returned conflicting results $(10,47)$.

Because the effect of mowing was more prevalent in PGRtreated turf, use of PGRs and mowing frequency may act in synergism to influence dollar spot. Less frequent mowing may facilitate increased turf growth because more leaf area is available for photosynthesis (24). This, combined with the increase in lateral shoot growth and improved turf recovery from mechanical or biotic damage that PGRs provide $(6,44)$, may reduce susceptibility to or improve recovery from dollar spot damage. In addition to growth rate, more frequent mowing combined with reduced vertical shoot growth from PGRs may increase canopy density $(24,44)$ and create a more favorable environment for disease development. For example, exacerbation of brown patch (incited by Rhizoctonia solani Kühn) on tall fescue turf has been associated with conditions that are found within more dense canopies such as higher relative humidity and longer durations of leaf wetness $(12,13)$.

In agreement with previous research $(3,5,15,26,42,43,49)$, these results suggest that trinexapac-ethyl provides limited and inconsistent dollar spot suppression in the absence of fungicides. It is possible that the benefit afforded by trinexapac-ethyl is evident only after turf has been conditioned by repeated applications. For example, several studies have reported improved tolerance of turf to abiotic stresses following treatment with trinexapac-ethyl $(28,36,48)$. Trinexapac-ethyl is not fungistatic toward $S$. homoeocarpa in vitro (3). However, nonfungistatic mechanisms have been suggested as potential influences on disease suppression $(3,15,49)$.

Table 5. Influence of mowing frequency (MF) on the duration of control of iprodione in 2007

\begin{tabular}{|c|c|c|c|c|}
\hline \multirow[b]{2}{*}{ Fungicide-MFy } & \multicolumn{4}{|c|}{ Survival analysis (days) ${ }^{x}$} \\
\hline & $n$ & $\mathbf{P}_{10}$ & $\mathrm{DOC}_{\mathrm{E}}$ & $P>\chi^{2 z}$ \\
\hline Iprodione & & & & 0.0334 \\
\hline 2 days week ${ }^{-1}$ & 48 & 12.4 & $23.8 \mathrm{a}$ & $\ldots$ \\
\hline 4 days week $^{-1}$ & 56 & 12.5 & $19.1 \mathrm{~b}$ & $\ldots$ \\
\hline 6 days week $^{-1}$ & 56 & 12.0 & $19.8 \mathrm{ab}$ & $\ldots$ \\
\hline
\end{tabular}

x Abbreviations: $n=$ the number of duration of control intervals used in analyses; $\mathrm{P}_{10}=$ the 10th percentile for duration of control was determined across plant growth regulators; $\mathrm{DOC}_{\mathrm{E}}=$ estimates of mean duration of control determined from Kaplan-Meier survival curves. $\mathrm{DOC}_{\mathrm{E}}$ values followed by the same letter are not significantly different at $P \leq 0.05$ according to Tukey's adjustment of multiple log-rank comparisons of survival curves.

${ }^{y}$ Fungicide treatments were initiated on 1 June 2007 and were reapplied when dollar spot exceeded a threshold of five infection centers plot ${ }^{-1}$.

${ }^{\mathrm{z}}$ Influence of MF was evaluated for significance at $P \leq 0.05$ by the logrank test for homogeneity of treatment survival curves when considered across plant growth regulators.
Prior to the initiation of the study, the hypothesis was that less frequent mowing and PGR use would reduce the amount of protected tissue removed and enhance fungicide residual efficacy; however, data from this study provide little support for this hypothesis. Despite substantial reductions in clipping yield by trinexapac-ethyl (unpublished data), use of this PGR did not appear to consistently influence the residual efficacy of boscalid, chlorothalonil, iprodione, or propiconazole. Similarly, although mowing frequency influenced clipping yields (unpublished data) and reduced dollar spot in the absence of fungicides, mowing frequency did not consistently influence the apparent residual efficacy of any fungicide in this study.

It is possible that mowing frequency and use of trinexapac-ethyl did not influence duration of control because their influence on clipping yields was not large enough during the short period when fungicides are most efficacious. Latin (25) found that the efficacy half-life of chlorothalonil, iprodione, and propiconazole on dollar spot control differed by less than 4.6 days despite large differences in the known field performance of these fungicides in turf. Although fungicides possessed appreciable residual efficacy up to 14 days after application, complete dollar spot control by chlorothalonil or iprodione had failed by the first sampling time ( 3 days after application) and prior to the second sampling (7 days) for propiconazole (25). Taken together, these data suggest that fungicide residual is important for dollar spot control only during a short period following application.

Survival analyses revealed that regular treatment with paclobutrazol extended the duration of dollar spot control afforded by boscalid, chlorothalonil, and iprodione in both years and propiconazole in 2008. When chlorothalonil was combined with paclobutrazol, the total amount of the fungicide applied in either study year was within the limits for golf course fairways $(29.13 \mathrm{~kg}$ a.i. $\mathrm{ha}^{-1}$ ) set by the Environmental Protection Agency. When used with trinexapac-ethyl or without a PGR, however, total chlorothalonil use exceeded this limit in most cases. The total amount of

Table 6. Influence of plant growth regulators (PGRs) on the duration of control of various fungicides on a 'Putter' creeping bentgrass fairway at the University of Connecticut in 2008

\begin{tabular}{lcccc}
\hline & \multicolumn{4}{c}{ Survival analysis (days) $^{\mathbf{x}}$} \\
\cline { 2 - 5 } Fungicide-PGR $^{\mathbf{y}}$ & $\boldsymbol{n}$ & $\mathbf{P}_{\mathbf{1 0}}$ & DOC $_{\mathbf{E}}$ & $\boldsymbol{P}>\boldsymbol{\chi}^{\mathbf{2 z}}$ \\
\hline Boscalid & & & & 0.0128 \\
PB & 24 & 32.0 & $55.6 \mathrm{a}$ & $\ldots$ \\
TE & 36 & 20.0 & $48.6 \mathrm{ab}$ & $\ldots$ \\
None & 36 & 14.5 & $39.8 \mathrm{~b}$ & $\ldots$ \\
Chlorothalonil & & & & 0.0006 \\
PB & 40 & 11.0 & $42.8 \mathrm{a}$ & $\ldots$ \\
TE & 68 & 8.7 & $25.4 \mathrm{~b}$ & $\ldots$ \\
None & 68 & 8.7 & $23.3 \mathrm{~b}$ & $\ldots$ \\
Iprodione & & & & 0.0286 \\
PB & 24 & 15.6 & $51.2 \mathrm{a}$ & $\ldots$ \\
TE & 44 & 9.3 & $34.3 \mathrm{ab}$ & $\ldots$ \\
None & 52 & 8.1 & $32.2 \mathrm{~b}$ & $\ldots$ \\
Propiconazole & & & & 0.0776 \\
PB & 24 & 27.8 & 56.1 & $\ldots$ \\
TE & 36 & 15.0 & 41.3 & $\ldots$ \\
None & 36 & 18.0 & 43.9 & $\ldots$ \\
\hline
\end{tabular}

${ }^{x}$ Abbreviations: $n=$ the number of duration of control intervals used in analyses; $\mathrm{P}_{10}=$ the 10th percentile for duration of control was determined across mowing frequencies; $\mathrm{DOC}_{\mathrm{E}}=$ estimates of mean duration of control determined from Kaplan-Meier survival curves. Within each fungicide, $\mathrm{DOC}_{\mathrm{E}}$ values followed by the same letter are not significantly different at $P \leq 0.05$ according to Tukey's adjustment of multiple log-rank comparisons of survival curves.

${ }^{y}$ Fungicide treatments were initiated on 30 May 2008 and were reapplied when dollar spot exceeded a threshold of five infection centers plot ${ }^{-1}$. PGRs paclobutrazol (PB) and trinexapac-ethyl (TE) were applied at approximately 21-day intervals.

${ }^{\mathrm{z}}$ Influence of PGRs was evaluated for significance at $P \leq 0.05$ within each fungicide by the log-rank test for homogeneity of treatment survival curves when considered across mowing frequencies. 


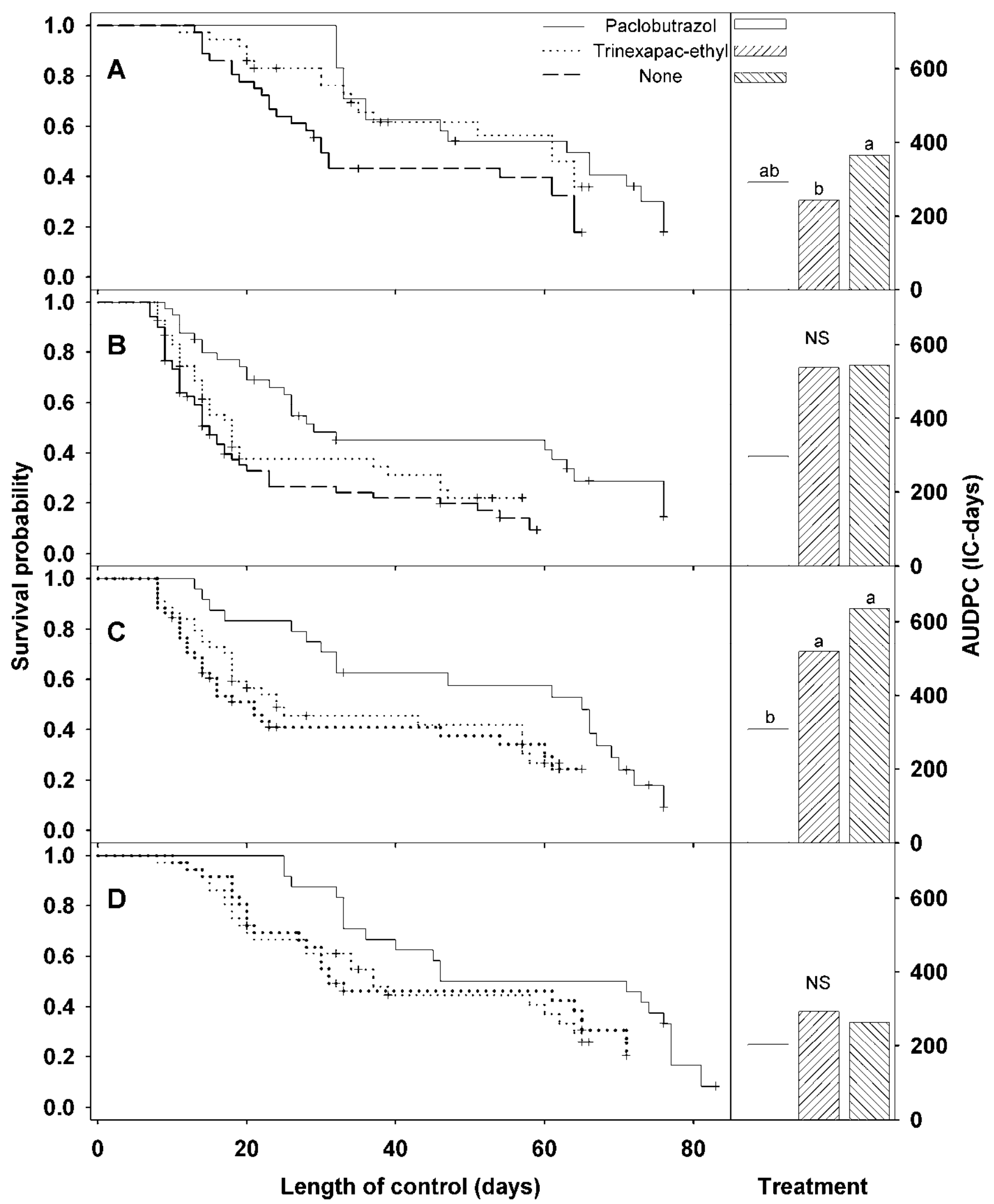

Fig. 4. Left panels: Kaplan-Meier estimates of survival functions describing duration of dollar spot control of A, boscalid, B, chlorothalonil, C, iprodione, or D, propiconazole as influenced by plant growth regulators (PGRs) in 2008. Censored observations (+) occurred when control in an individual plot had not failed when the fungicide treatment was reapplied. Right panels: area under the disease progress curve (AUDPC) values determined from daily assessment of the number of dollar spot infection centers plot ${ }^{-1}$. The AUDPC data were subjected to an analysis of variance and bars with the same letter are not significantly different according to Fisher's protected least significant difference $t$ test at $P \leq 0.05$. NS indicates that the influence of PGRs was not significant for that fungicide. AUDPC data were $\log _{10}$ transformed prior to analysis but actual means are shown. Plant growth regulators were applied at approximately 21-day intervals, but fungicides were reapplied only after control from the previous application failed based on mean disease values exceeding five infection centers plot $^{-1}$. 
boscalid, iprodione, and propiconazole applied during each season was considerably less than the limit set by label restrictions for each fungicide, regardless of PGR use.

Due to similarities to the DMI fungicides, repeated application of paclobutrazol or related PGRs may exert a selection pressure leading to the development of an S. homoeocarpa population with reduced sensitivity to this class of PGRs or DMI fungicides $(3,23)$. Due to the prevalence of populations of the pathogen with reduced sensitivity to the DMIs $(18,22,35)$, caution should be exercised when using this class of fungicides and related PGRs together. At the University of Connecticut, no reduction in field performance of the DMIs has been observed in annual field trials. In a limited survey of fields adjacent to this study site, 3 of $10 \mathrm{~S}$. homoeocarpa isolates exhibited moderately reduced in vitro sensitivity to propiconazole (35). Although $S$. homoeocarpa with reduced sensitivity to paclobutrazol has been reported (33), the influence of these PGRs on resistance development is poorly understood.

This study demonstrates the practical value of scheduling fungicide applications for control of dollar spot based on disease thresholds. At several points during the study, durations of control were achieved that exceeded the application interval recommended on the fungicide's labels, indicating that a threshold-based application timing may reduce fungicide use (41). During periods of high disease pressure, the threshold strategy detected when disease control failed earlier than expected and likely prevented damaging epidemics. Although this strategy was highly effective for both acropetal penetrants in this study, the higher AUDPC values observed for boscalid compared with propiconazole in 2007 support anecdotal claims that the fungicidal activity of boscalid is delayed following application when compared with other acropetal penetrants such as propiconazole $(8,14)$. However, a separate, post-hoc survival analysis based on time to recovery $\left(\leq 1\right.$ infection center plot $\left.^{-1}\right)$ revealed that recovery times were similar for both fungicides (unpublished data). In contrast to the high effectiveness of acropetal penetrants used in a threshold-based application regime, contact or localized penetrants fungicides are less likely to provide adequate suppression when used alone.

\section{Acknowledgments}

Funding for this research was generously provided by the New England Regional Turfgrass Foundation. Additional financial support was provided by Syngenta Crop Protection and the United States Golf Association. We thank M. Fidanza and P. Ojiambo for reviewing portions of the manuscript; anonymous reviewers for their suggestions; K. Guillard for helpful comments; and D. Bradnan, A. DeVaux, J. Machnicki, and D. McIntyre for their assistance.

\section{Literature Cited}

1. Abernathy, S. D., White, R. H., Colbaugh, P. F., Engelke, M. C., Taylor, G. R., III, and Hale, T. C. 2001. Dollar spot resistance among blends of creeping bentgrass cultivars. Crop Sci. 41:806-809.

2. Allison, P. D. 1995. Survival Analysis Using SAS: A Practical Guide. SAS Institute, Inc., Cary, NC.

3. Burpee, L. L., Green, D. E., and Stephens, S. L. 1996. Interactive effects of plant growth regulators and fungicides on epidemics of dollar spot in creeping bentgrass. Plant Dis. 80:1245-1250.

4. Campbell, C. L., and Madden, L. V. 1990. Introduction to Plant Disease Epidemiology. John Wiley \& Sons, New York.

5. Clarke, B. B., Majumdar, P., and Hlubik, W. 1995. Preventive control of dollar spot with selected fungicides and subsequent impact on brown patch, 1994. Fungic. Nematicide Tests 50:341-342.

6. Dernoeden, P. H. 2000. Creeping Bentgrass Management: Summer Stresses, Weeds, and Selected Maladies. John Wiley \& Sons, Hoboken, NJ.

7. Dickinson, L. S. 1930. The effect of air temperature on the pathogenicity of Rhizoctonia solani parasitizing putting green turf. Phytopathology 20:597608.

8. Dillard, H., and Cobb, A. 2009. Sclerotinia sclerotiorum-considerations for control on snap beans in New York State. In: Proc. 14th Int. Sclerotinia Workshop, Wilmington, NC. http://www.plantmanagementnetwork.com/ sub/proceedings/Sclerotinia/2009/Dillard.pdf

9. Donaghy, D. J., and Fulkerson, W. J. 1998. Priority for allocation of watersoluble carbohydrate reserves during regrowth of Lolium perenne. Grass Forage Sci. 53:211-218.

10. Ellram, A., Horgan, B., and Hulke, B. 2007. Mowing strategies and dew removal to minimize dollar spot on creeping bentgrass. Crop Sci. 47:21292137.

11. Fidanza, M. A., Wetzel, H. C., III, Agnew, M. L., and Kaminski, J. E. 2006.
Evaluation of fungicide and plant growth regulator tank-mix programmes on dollar spot severity of creeping bentgrass. Crop Prot. 25:1032-1038.

12. Giesler, L. J., Yuen, G. Y., and Horst, G. L. 1996. Tall fescue canopy density effects on brown patch disease. Plant Dis. 80:384-388.

13. Giesler, L. J., Yuen, G. Y., and Horst, G. L. 1996. The microclimate in tall fescue turf as affected by canopy density and its influence on brown patch disease. Plant Dis. 80:389-394.

14. Gilstrap, D. M., and Vargas, J. M., Jr. 2005. Don't panic with Emerald. In: 75th Annu. Michigan Turfgrass Conf. East Lansing, MI.

15. Golembiewski, R. C., and Danneberger, T. K. 1998. Dollar spot severity as influenced by trinexapac-ethyl, creeping bentgrass cultivar, and nitrogen fertility. Agron. J. 90:466-470.

16. Harrell, F. E., Jr. 2001. Regression Modeling Strategies: With Applications to Linear Models, Logistic Regression, and Survival Analysis. SpringerVerlag, New York.

17. Howieson, M. J., and Christians, N. E. 2008. Carbohydrate metabolism and efficiency of photosystem II in mown creeping bentgrass (Agrostis stolonifera L.). HortScience 43:525-528.

18. Jo, Y.-K., Niver, A. L., Rimelspach, J. W., and Boehm, M. J. 2006. Fungicide sensitivity of Sclerotinia homoeocarpa from golf courses in Ohio. Plant Dis. 90:807-813.

19. Kaminski, J. E., and Fidanza, M. A. 2009. Dollar spot severity as influenced by fungicide mode of activity and spray nozzle. HortScience 44:1762-1766.

20. Kaplan, E. L., and Meier, P. 1958. Nonparametric estimation from incomplete observations. J. Am. Stat. Assoc. 53:457-481.

21. Klein, J. P., and Moeschberger, M. L. 2003. Survival Analysis: Techniques for Censored and Truncated Data, 2nd ed. Springer, New York.

22. Koch, P. L., Grau, C. R., Jo, Y.-K., and Jung, G. 2009. Thiophanate-methyl and propiconazole sensitivity in Sclerotinia homoeocarpa populations from golf courses in Wisconsin and Massachusetts. Plant Dis. 93:100-105.

23. Köller, W. 1988. Sterol demethylation inhibitors: mechanisms of action and resistance. Pages 79-88 in: Fungicide Resistance in North America. C. J. Delp, ed. American Phytopathological Society, St. Paul, MN.

24. Krans, J. V., and Beard, J. B. 1985. Effects of clipping on growth and physiology of Merion Kentucky bluegrass. Crop Sci. 25:17-20.

25. Latin, R. 2006. Residual efficacy of fungicides for control of dollar spot on creeping bentgrass. Plant Dis. 90:571-575.

26. Lickfeldt, D. W., Gardner, D. S., Branham, B. E., and Voigt, T. B. 2001 Implications of repeated trinexapac-ethyl applications on Kentucky bluegrass. Agron. J. 93:1164-1168.

27. Markland, F. E., Roberts, E. C., and Fredrich, I. R. 1969. Influence of nitrogen fertilizer on Washington creeping bentgrass, Agrostis palustris Huds. II. Incidence of dollar spot, Sclerotinia homoeocarpa, infection. Agron. J. 61:701-705.

28. McCann, S. E., and Huang, B. R. 2007. Effects of trinexapac-ethyl foliar application on creeping bentgrass responses to combined drought and heat stress. Crop Sci. 47:2121-2128.

29. McDonald, S. J., Dernoeden, P. H., and Bigelow, C. A. 2006. Dollar spot and gray leaf spot severity as influenced by irrigation, chlorothalonil, paclobutrazol, and a wetting agent. Crop Sci. 46:2675-2684.

30. Mercier, J. 1999. Use of the growth regulator paclobutrazol in the management of dollar spot of creeping bentgrass in Minnesota. Phytoprotection 80:65-70.

31. Murphy, K. C., Cooper, R. J., and Clark, J. M. 1996. Volatile and dislodgeable residues following triadimefon and MCPP application to turfgrass and implications for human exposure. Crop Sci. 36:1455-1461.

32. Neely, D. 1970. Persistence of foliar protective fungicides. Phytopathology 60:1583-1586.

33. Ok, C-H., Popko, J. T., Campbell-Nelson, K., and Jung, G. 2011. In vitro assessment of Sclerotinia homoeocarpa resistance to fungicides and plant growth regulators. Plant Dis. 95:51-56.

34. Orshinsky, A. M., and Boland, G. J. 2009. Colonization of nonwounded and wounded creeping bentgrass (Agrostis stolonifera) by virulent and hypovirulent isolates of Sclerotinia homoeocarpa. (Abstr.) Phytopathology 99:S97.

35. Putman, A. I., Jung, G., and Kaminski, J. E. 2010. Geographic distribution of fungicide-insensitive Sclerotinia homoeocarpa isolates from golf courses in the northeastern United States. Plant Dis. 94:186-195.

36. Rossi, F. S. 2001. Annual bluegrass population dynamics in response to growth regulators and herbicides. Int. Turfgrass Soc. Res. J. 9:906-909.

37. Scherm, H., and Ojiambo, P. S. 2004. Applications of survival analysis in botanical epidemiology. Phytopathology 94:1022-1026.

38. Seiber, J. N. 1985. General principles governing the fate of chemicals in the environment. Pages 389-401 in: Agricultural Chemicals of the Future. Beltsville Symposia in Agricultural Research VIII. J. L. Hilton, ed. Rowan and Allanheld, Totown, NJ.

39. Sigler, W. V., Taylor, C. P., Throssell, C. S., Bischoff, M., and Turco, R. F. 2000. Environmental fates of fungicides in the turfgrass environment: a minireview. Pages 127-149 in: Fate and Management of Turfgrass Chemicals. J. M. Clark and M. P. Kenna, eds. American Chemical Society, Washington, DC.

40. Smiley, R. W., Dernoeden, P. H., and Clarke, B. B. 2005. Compendium of Turfgrass Diseases, 3rd ed. American Phytopathological Society, St. Paul, MN

41. Smith, D. L., and Kerns, J. P. 2010. Using a logistic regression model to 
advise fungicide sprays for the control of dollar spot of creeping bentgrass putting greens. Am. Soc. Agron. Abstr. 74-7.

42. Soika, M. D., and Tredway, L. P. 1997. Evaluation of fungicides for control of dollar spot, 1996. Fungic. Nematicide Tests 52:374-375.

43. Stewart, J. M., Latin, R., Reicher, Z., and Hallett, S. G. 2008. Influence of trinexapac-ethyl on the efficacy of chlorothalonil and propiconazole for control of dollar spot on creeping bentgrass. Appl. Turfgrass Sci. Online publication. doi:10.1094/ATS-2008-0319-01-RS.

44. Turgeon, A. J. 2005. Turfgrass Management, 7th ed. Pearson Education, Upper Saddle River, NJ.

45. Vargas, J. M., Jr. 2005. Management of turfgrass diseases. 3rd ed. John Wiley \& Sons, Hoboken, NJ.
46. Walsh, B., Ikeda, S. S., and Boland, G. J. 1999. Biology and management of dollar spot (Sclerotinia homoeocarpa); an important disease of turfgrass. HortScience 34:13-21.

47. Williams, D. W., Powell, A. J., Jr., Vincelli, P., and Dougherty, C. T. 1996. Dollar spot on bentgrass influenced by displacement of leaf surface moisture, nitrogen, and clipping removal. Crop Sci. 36:1304-1309.

48. Xu, Y., and Huang, B. R. 2010. Responses of creeping bentgrass to trinexapac-ethyl and biostimulants under summer stress. HortScience 45:125-131.

49. Zhang, X., and Schmidt, R. E. 2000. Application of trinexapac-ethyl and propiconazole enhances superoxide dismutase and photochemical activity in creeping bentgrass (Agrostis stoloniferous var. palustris). J. Am. Soc. Hortic. Sci. 125:47-51. 